\title{
69
}

\section{SIR THOMAS MORE}

I 984

$\begin{array}{l:l}\text { Opening Date August } 1984 & \text { Director Phoebe Wray } \\ \text { Venue Globe Playhouse, Los Angeles, CA } & \text { Costumes Cathy Crane } \\ \text { Company Shakespeare Society of America } & \end{array}$

CAST

Mistress Roper Kit Van Zandt

Thomas More Thom Koutsoukos

Lady More Jensen Collier

"Sir Thomas More" is finally making its American bow at the Globe Playhouse ... Phoebe Wray added a few references to Henry's clash with the Pope..."Sir Thomas More" is a mildly interesting testimonial, but not much of a drama. The script emphasizes More's sense of fun and his remarkable poise in the face of death... But many of his jokes have lost their humor over the centuries and seem especially trivial in the absence of scenes that explicitly come to grips with his dilemma. The best part occurs before the first intermission, when More persuades an unruly mob to surrender to the authorities who promptly hang one of the rebels before More has a chance to save him ... However, this is hardly the central crisis of the play ... This first act seems like a separate play, and even here the dramaturgy is flawed; for example, we never see More's response to the news that one of those who followed his advice was hanged because of it. Thom Koutsoukos looks like More... but his line readings are only intermittently effective. Although Jensen Collier registers strongly as More's wife, some supporting roles are woefully miscast. Wray keeps the stage in motion and makes a few unexpected choices in her blocking. But whatever possessed the uncredited set designer to tack strips of bright red carpet to the front of the scaffold that supports the gallows? (Don Shirley, Los Angeles Times, 17 August 1984) 